\title{
It Is Worth Its Weight in Gold: The Swiss Franc in the 1930's
}

\author{
Guillaume Vallet ${ }^{1, *}$ \\ ${ }^{1}$ Department of Economics, Centre de Recherche en Economie de Grenoble (CREG), France \\ *Correspondence: Department of Economics - Centre de Recherche en Economie de \\ Grenoble (CREG), BP 47 - 38040 Grenoble cedex 9, France \\ E-mail: guillaume.vallet@upmf-grenoble.fr
}

Received: December 11, 2013 Accepted: January 16, 2014 Published: February 3, 2014 doi:10.5296/rae.v6i1.5044ＵRL: http://dx.doi.org/10.5296/rae.v6i1.5044

\begin{abstract}
Switzerland is perceived as a unique country. Economic and financial explanations have to be linked to monetary, social and political reasons too. It means that money matters in Switzerland because it is a small, open and multicultural country that needs a strong common anchor in order to exist. This is why we will focus on the key period of the 1930's when the choice to implement the Gold Stallion was more than a technical and monetary choice: it also played the role of a social and political anchor for the Swiss society as a whole to federate.
\end{abstract}

Keywords: Switzerland; monetary policy; Swiss franc; gold standard; money

JEL Classification: B 22; E 42; E 58; N 24 


\section{Introduction}

Switzerland has often been cited by other countries as a 'deviant' country for a long time particularly since the beginning of the current crisis in 2007. Indeed, the Swiss financial and legal system is at the core of the International Financial System's turbulence because of its particularities like banking secrecy or specific legislation. Such an environment could lead to financial trade diversion and even unfair trade. However the country has suffered from this crisis too. It is because the Swiss franc plays the role of a safe haven currency (Ranaldo \& Söderlind, 2010; Coudert \& Raymond, 2011): when economic or political problems occur in the world, the international economic actors suddenly tend to strongly invest in Switzerland, shifting their capital there. As Swiss financial markets are relatively narrow, this higher demand for assets in Swiss franc leads to a massive appreciation of this currency against other major international currencies, which is uncorrelated with the national economic fundamentals. This could be problematic because in spite of the national specialization in high value added sectors, a strong jeopardizes Swiss exports (Lampart, 2011).

This is the case for the Swiss franc/euro nominal exchange rate. The appreciation of this parity was so strong during the summer 2011 that the Swiss National Bank (SNB) decided to implement an official peg to the euro on September 6th 2011 even if this was to lower its monetary autonomy (Guillaumin \& Vallet, 2012). But the sense of this extreme measure has to be clarified: it has not been taken to prepare Switzerland's accession to the EU as it is not a full member yet and even historically, it has always been reluctant to the EU full membership (Vallet, 2012). Conversely, the determinant of such a choice is to preserve national monetary sovereignty that is to say to preserve the Swiss franc as a specific and national asset and then to avoid being integrated into a wide external monetary zone (Ponsot \& Vallet, 2012). This will to maintain its monetary independence is naturally defended by banking and financial circles because it directly serves their interests (UBS, 2000; Schriber, 2007). But they are also supported by the industrial sector, the SNB and the Federal Council who all want to preserve the Swiss monetary independence and its national currency.

Such a national coalition actually finds its roots in the 1930's. During this special period for the Swiss history, the SNB chose to implement a very binding monetary rule with the consent and support of the three sectors mentioned above. The SNB was to define the Swiss franc in a strict weight of gold, which is the so-called Gold Standard. This monetary regime allowed the country to attract higher amounts of capital inflows internationally and hence to reinforce all the national financial competitive advantages like the "Swiss interest rates bonus" (Kugler \& Weder, 2009). But it led to another crucial benefit that is rarely put into the light: as the Gold Standard improved the national prosperity, an ideology of a necessary stable money was born in Switzerland during this period. More widely, the Swiss franc embodied the symbol of the Swiss unity and identity in a very diversified and open country. In other words, the national currency was perceived as the central material that stabilized a country which was already at at the center of centrifuge and centripetal forces during that time. That is why the Gold Stallion used to play a great role in this economic, social and political construction. 
Hence we shall attempt to explain in this paper to what extent such a monetary regime has had a real weight in the Swiss history from two angles. The first will show that the Gold Standard was chosen to participate in the national prosperity in a world in turmoil. Hence we will secondly argue that the latter was for defended by the main national economic and political actors because there were strong sociological stakes too beyond the sole economic ones.

\section{The Choice of the Gold Standard: How to Construct a Solid Economy Thanks To the Attractiveness of the International Capital Whatever the Costs}

\subsection{The banking and financial motivations to adopt such a monetary regime}

At the end of the 1920's, Switzerland's economic situation was ambivalent: as a member of the Latin Monetary Union (LMU) since 1865, it had experienced difficulties to really set up an autonomous monetary policy that would suit the national interests. Indeed, such a monetary union was facing internal problems, due to a desynchronization of the business cycles between its members and with regards to the prices of silver and gold their national currencies were linked to. On the other hand, those problems had led to numerous capital inflows in Switzerland, because the country was perceived to have the strongest economy. Indeed, contrary to other LMU members such as France, Switzerland had not been directly affected by World War I (WWI) thanks to its neutrality. This situation allowed Switzerland to attract high and growing capital investments from 1914, which has participated to the development of the banking and financial sector (Mazbouri, 2005).

That is why after the end of the LMU in 1927, both Switzerland's economic and political authorities wanted to maintain and even to make this advantage grow. Indeed, if it led to the construction of a direct competitive advantage in the banking and financial sector, it seemed to be good for the national economy as a whole. More precisely, high amounts of capital induce a low cost of it, namely weak interest rates, which is in sync with the industrial interest. For a country which possesses an industrial basis inherited from the textile, railroads and watch industries that were born during the 19th century (Boson, 1965), low interest rates offer the possibility of high value added investment and then a better productive stance. This is crucial for a country which has limited raw materials, demography and faces strong geographic constraints.

So in the hope of attracting international capital flows in the troubled world of the late 1920's, it was necessary to build a monetary system that would reassure the investors. In other words, as the economic and monetary forecasts seemed to be unclear, to set up a stable monetary regime in Switzerland was a good mean to maintain a high level of capital inflows. From an economic point of view, a fixed parity is indeed a stabilizer because it imposes a monetary discipline, lowering the national economy's volatility as some literature indicates (Clarida \& Gali, 1994; Calvo \& Reinhart, 2002). In the case of Swiss open economy, this is also a central argument to envisage the implementation of such a monetary regime. 
The Swiss monetary authorities were also sceptical about the credibility of the international monetary system. Since the Genes' Conference in 1922, the majority of the developed countries' central banks had decided to de facto remove the link between their currencies and gold. Instead of gold, they accepted other currencies to create money because they were considered as good as gold. But the SNB did not trust this "Exchange Gold Standard" and, by the end of the1920's, started to sell its foreign currencies it had in its balance sheet.

That is why the Swiss political authorities decided in 1929 to promulgate a law in favour of the choice of the Golden Standard that have actually been in discussion since 1924. The latter, entered into force in 1931, clearly defined, for the first time in the history of the country, a strict parity between the national currency and a weight of gold (Cruchon, 1932).

This policy gave good results very quickly: for instance, to deal with the new Swiss international financial status, the Swiss National Bank created 300 millions of Swiss francs in 1930 to convert new foreign amounts of investments. The international investors saw Switzerland as a monetary haven where they could invest without any problems (Müller, 2003). Thanks to this, the Swiss central bank appeared more credible internationally because over the time it became one of the last central banks which really wanted to preserve the Gold Standard. Indeed, important economic countries like Germany (1931), Britain (1931) and the United States (1933) decided to officially give up such a monetary regime. Hence, due to those choices and moreover with the Great Depression in 1929, Switzerland appeared to be a small but solid monetary island in an ocean of international troubles. Furthermore, the political decision in 1934 to set up a better juridical environment for investors through a law that protected banking secrecy sustained efforts in that direction: it gave a signal to Swiss domestic as well as international investors, that they could invest in Switzerland because their capital would be warranted in a total discretion.

But if such measures indeed entailed strong inflows of capital, another important consequence was nevertheless the strong appreciation of the national currency which tended to weaken the Swiss economy.

\subsection{The consequences of a peg to gold: the Gold Standard as a burden?}

If the decision to officially adopt a peg of the national currency to gold in 1931 reinforced Switzerland's attractiveness for capital investors, at the same time it led to strongly jeopardize several economic sectors. Though the latter would have needed some economic support through Keynesian policies due to the poor economic context, the will to maintain such a monetary regime necessitated orthodox economic policies - both monetary and fiscal ones - to preserve the value of the money, implying a non-interventionist State. Indeed, "the Federal council and the National bank know that a permanent government fiscal imbalance would lead to hostile forecasts as far as the future of our currency is concerned. To allow a strong confidence in it and to preserve our credit, we need, through an immediate and sufficient effort, to establish a positive balance in the government's budget." (Federal Council, 1933, p 203). 


\section{Mll Macrothink}

Concretely, these economic policies induced deflation because of the control of the government spending and moreover because of the appreciation of the national currency against the others. As international investors were attracted by Swiss financial place, more capital inflows entered into the country. This entailed a rise in the demand for Swiss franc assets and a subsequent appreciation of the Swiss franc because of the relative narrowness of the local financial markets, following the same process as today with the Swiss franc as safe haven currency. The fact that other countries decided at the same time to devalue their currencies-as we have noticed above was in favor of Switzerland from this point of view (Müller, 2003; Zurlinden, 2003).

Nevertheless, if banking and financial activities in Switzerland benefited from those higher amounts of capital, the induced appreciation led to a strong decrease in external trade too. More precisely, higher Swiss prices in purchasing power parity in an international comparison led to an increase of imports and a decrease of exports, as the graphs below illustrate (Figure 1 and Figure 2)

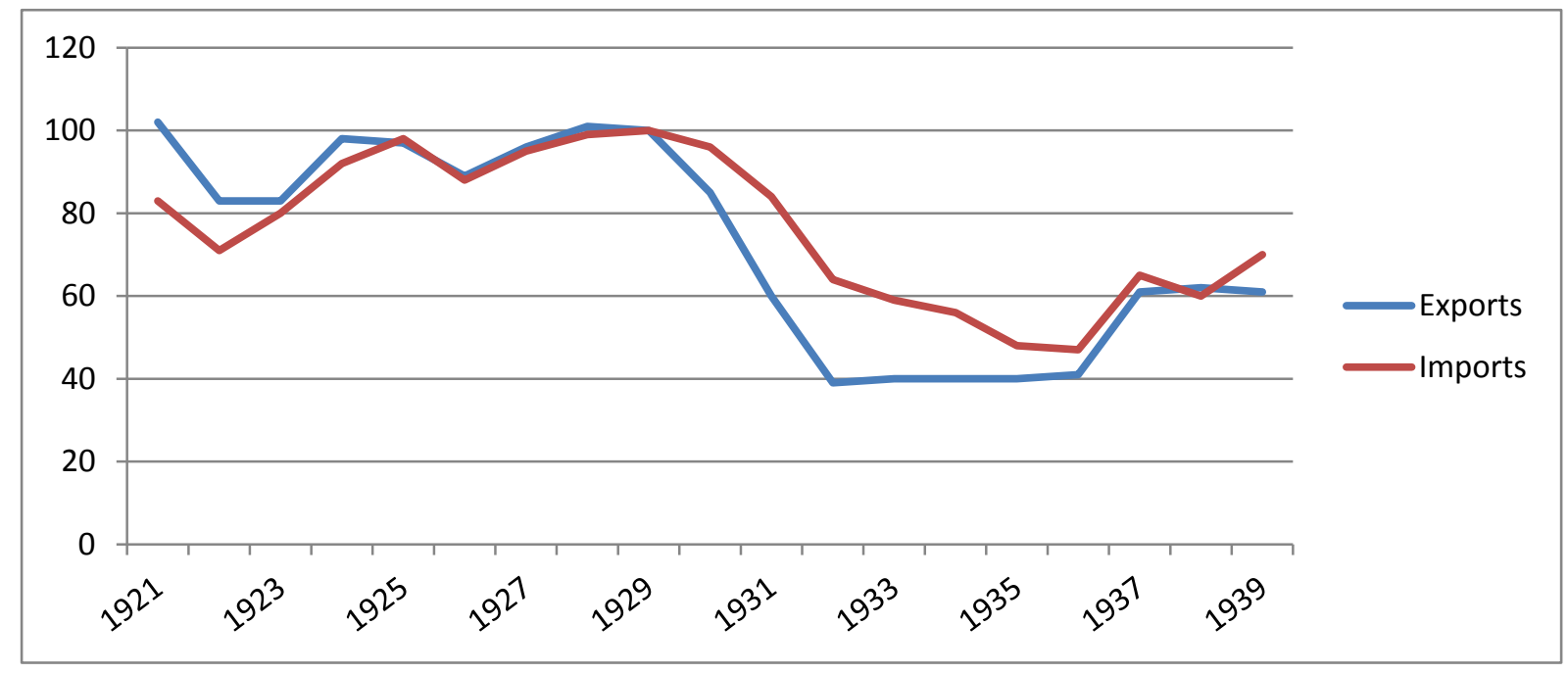

Source: Bordo \& alii, 2006.

Figure 1. Swiss Foreign Trade: Exports and Imports of Goods (in nominal prices) 


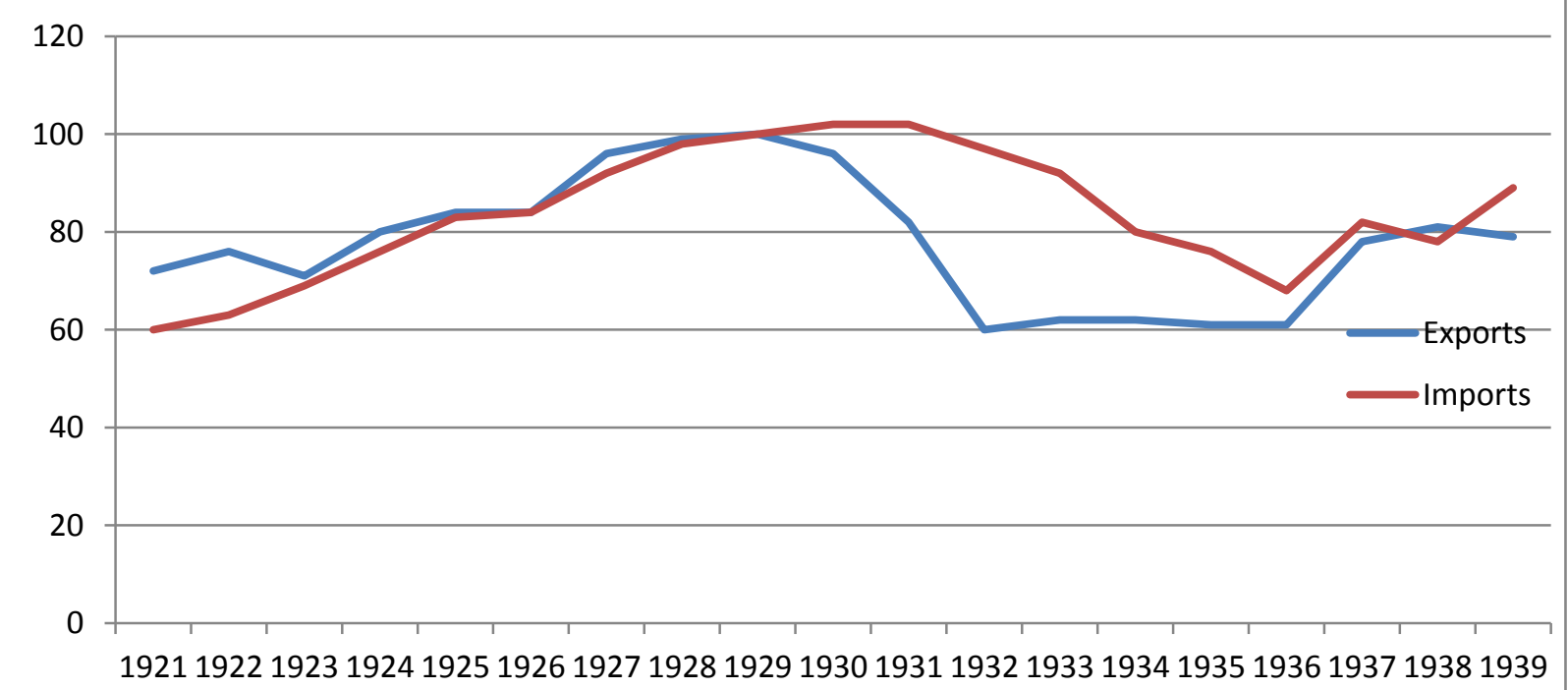

Source: Bordo \& alii, 2006.

Figure 2. Swiss Foreign Trade: Exports and Imports of Goods (in constant prices)

Important sectors like the goods industry (chemistry, pharmacy, machines,...), agricultural products and also some services (hotel and catering industry) strongly suffered from this situation, maybe because such a monetary regime failed to prevent the volatility of the Swiss franc. Figure 3 shows indeed that the major periods of exchange rate instability occurred during the Gold Standard:

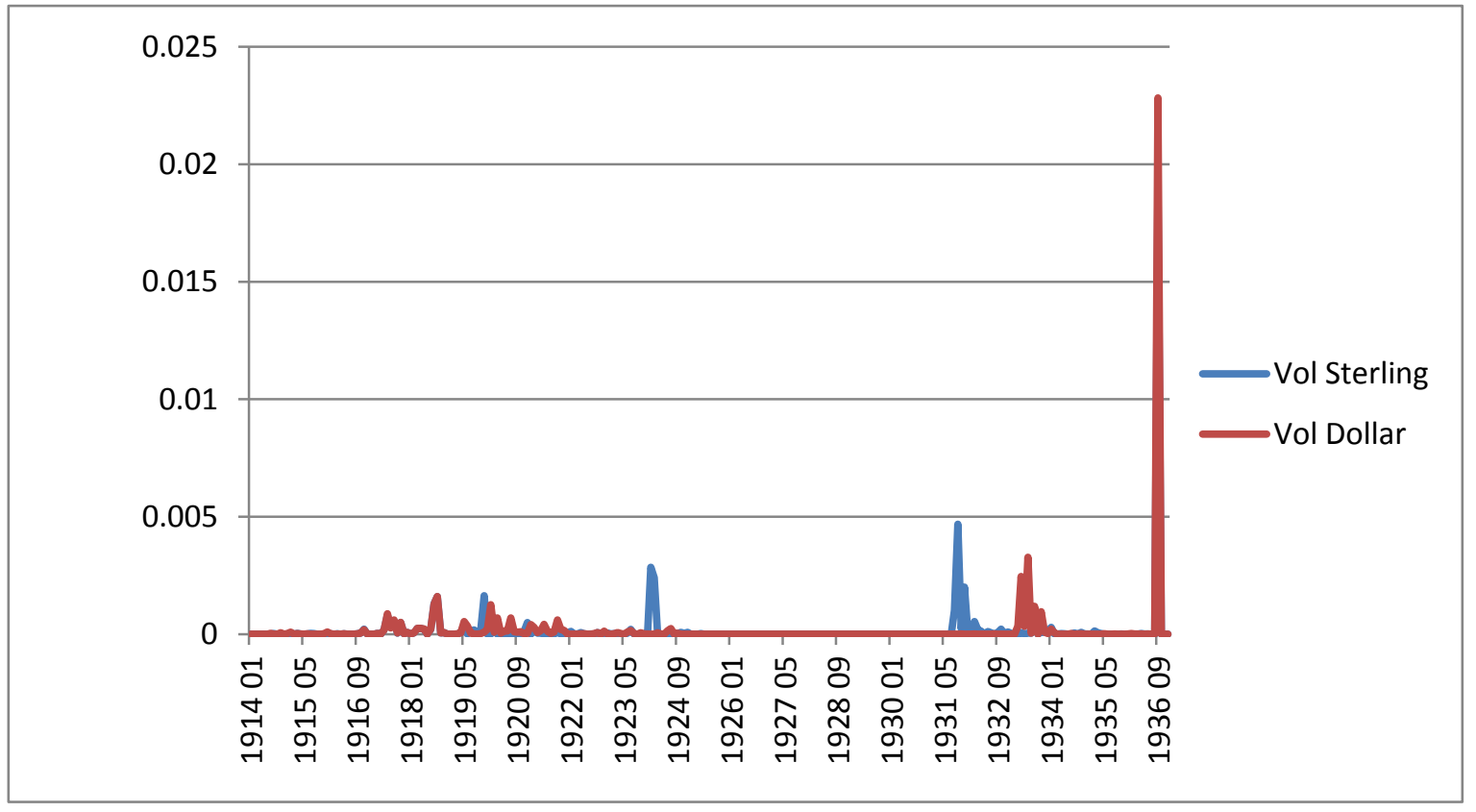

Source : Author's calculations ; Data from the Swiss National Bank, 2013.

Figure 3. Volatility of the Nominal Swiss franc Exchange Rate against Dollar and Sterling Pound (01:1914-11:1936) 


\section{Macrothink Institute ${ }^{\text {TM }}$}

This indicates that the Gold Standard acted as a burden for the Swiss economy because it prevented fiscal and monetary policies from stabilizing the economy. From a monetary perspective, a devaluation could have boosted the activity. For instance, if Switzerland had devalued at the same time as Britain in 1931, the output level in 1935 would have been some $18 \%$ higher than it actually was in that same year. In the same perspective, if there had been a devaluation in 1933 like the United States did in that year, the increase of real GDP would have been $15 \%$ higher (Bordo \& alii, 2006). In spite of these strong negative effects, Swiss official authorities (the SNB in agreement with the Federal Council) waited till the year 1936 to devalue the national currency - one of the last European countries to do it at that time fearing that such a decision would imply capital outflows and consequently jeopardize Swiss prosperity.

In a same perspective, figures 4 to 7 indicate that other monetary options like a peg to other currencies would have had better effects on several variables if they had been taken in 1929 instead of the Gold Standard:

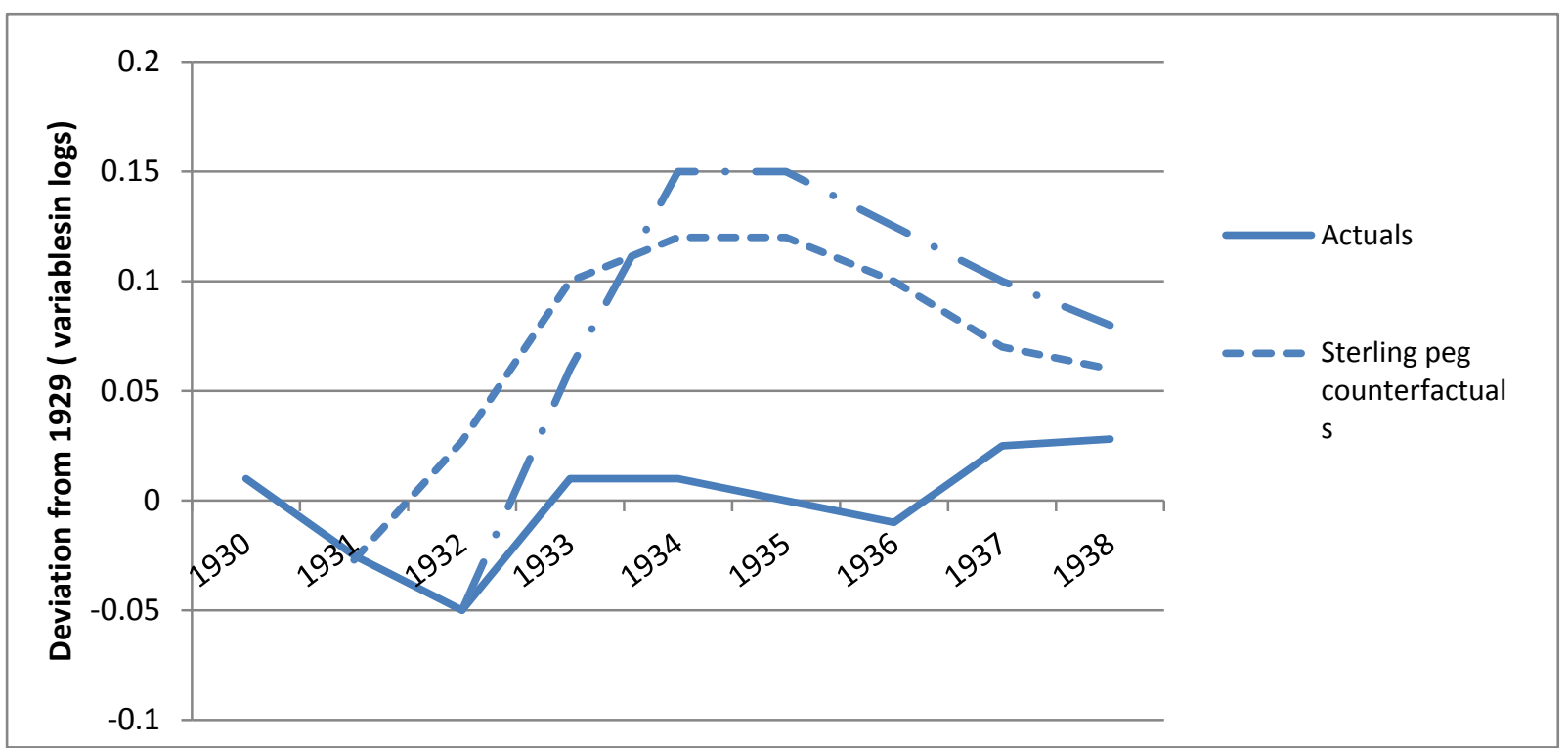

Source: Bordo \& alii, 2006.

Figure 4. Output in Switzerland with a peg 


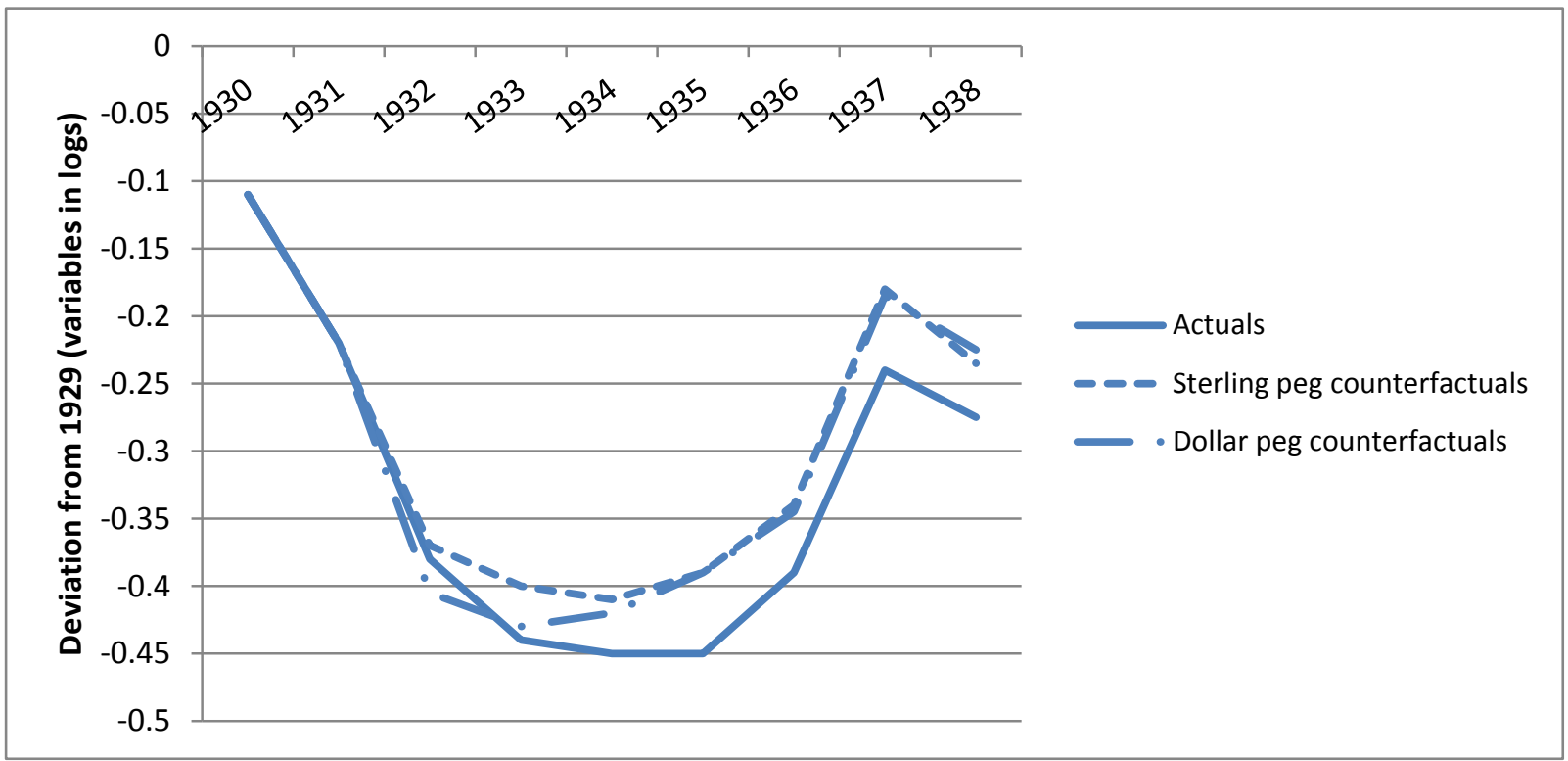

Source: Bordo \& alii, 2006.

Figure 5. Prices in Switzerland with a peg

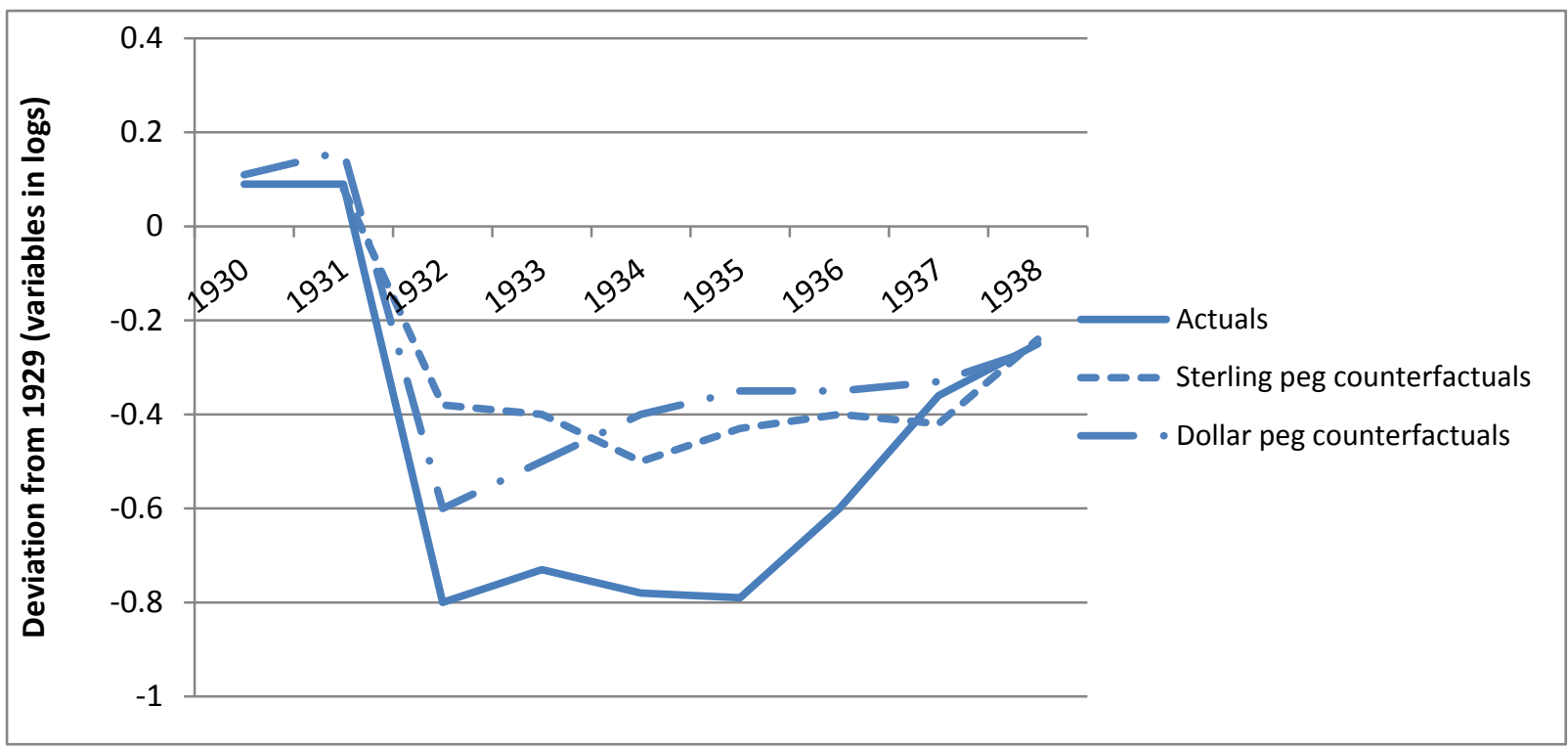

Source: Bordo \& alii, 2006.

Figure 6. Swiss Exports to Sterling Bloc with a peg 


\section{Macrothink}

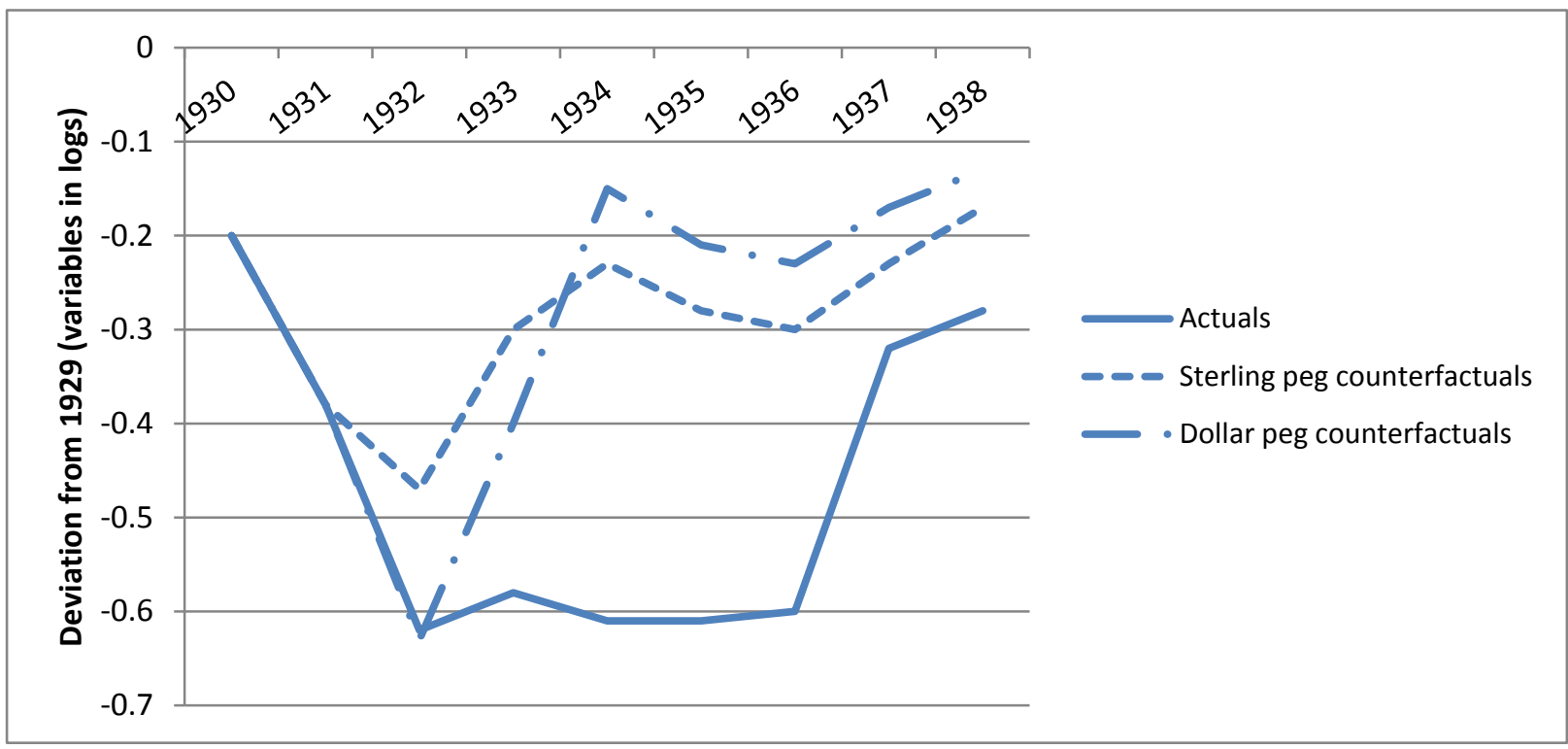

Source: Bordo \& alii, 2006

Figure 7. Swiss Exports to Dollar Bloc with a peg

As we can see, the real situation linked to the Gold Standard (in straight line) is always less optimal than the two other options (dotted lines).

In sum, the will to set up and maintain such a monetary regime during the 1930's seems to be clearly too high a price to pay.

So what were the reasons to maintain it? Were there any other interests that have to be revealed here? We shall answer to these questions in the second part, which follows a sociological perspective.

\section{The Weight of the Gold Standard: the Swiss Franc, More than an Economic Asset}

\subsection{The Gold Standard as a Golden Age? A sociological perspective}

To adopt a sociological perspective for monetary issues is quite rare because money is " $a$ persistent but not a dominant topic in sociology" (Baker \& Jimerson, 1992, p 678). In spite of Simmel's pioneer work on money (Simmel, 1999), monetary topics have often been directly treated in social sciences only by historians or economists and not by sociologists. So we attempt to follow a different approach in this paper: money is not only perceived here as a medium of exchange, a means of payment, a store of value, a unit of account or a standard for deferred payments (Dalton, 1967). Money is above all both a symbol and a material reality allowing the people of a geographical and political area, generally the nation State, to be linked to each other and to differ from foreigners. In other words, money participates in creating and reinforcing national identity because it gathers people (identite-idem) while distinguishing (identite-ipse). Thus this vision confers a different societal role for money because it shows that the economy can be a subordinate to society. 
But that means that money is 'violent' (Aglietta \& Orléan, 2002): it is the result of the choices of the citizens, that is the social conflicts inside a country. Money is and has to be a symbol of the democratic debates because it embodies the economic preferences that arise from conflicts, because democracy is conflicts (Touraine, 1994). That explains why one can also observe that money is a social and political construction. As money is about power from a national and international point of view, the main economic and politic national actors want it to suit their interests. It means that conflicts have to be analyzed through their nature first, that is the distribution of the resources. That is why Weber used to argue that "money prices are the product of conflicts of interest and of compromises; they thus result from power constellations. Money is not a mere 'voucher for unspecified utilities' which could be altered at will without any fundamental effect on the character of the price system as a struggle of man against man. 'Money' is rather, primarily a weapon in this struggle." (Weber, 1922, p 108)

What is interesting in the Swiss case is to comprehend that the defense of the monetary regime of the Gold Standard was a real internal struggle in order to preserve the value and the existence of the national currency. We have seen above that its negative economic effects could have normally led to unpopularity. But it was not the case. The main Swiss economic and political actors succeeded in building a 'Gold Standard Mentality' (Eichengreen \& Temin, 2000) that was not only shared by institutions like the banking and financial industry, the SNB or the Federal Council but by others too.

Indeed, the banking and financial industry that have worried about the preservation of the Swiss franc stability and then of its particularities in the 1930's turbulent times officially wants to defend the Gold Standard. Behind the scene, they have nevertheless speculated on its collapse during the years before the devaluation in 1936 too, showing their ambivalent position. For instance, although they are officially strongly in favor of the Gold Standard, the Swiss banks are among the speculators that have attacked the Swiss franc between 1933, April $15^{\text {th }}$ and 1933 , July $7^{\text {th }}$ - when the SNB has lost an important part of its stock of gold for an amount of 716 million of Swiss francs - or in April 1934 (Adank \& alii, 2002, pp 58-61). And finally, they weakly react to the devaluation in 1936. So the support to the monetary regime has to come from elsewhere.

Such a support comes from the goods industry on the whole which is strongly interested in the implementation of such a 'national preference structure' (Müller, 2003). On one hand, it is true that it highly suffered from the appreciation of the national currency induced by this hard monetary regime, because of the drop of their exportations. On the other hand, due to the fact that the Gold Standard induced high levels of capital inflows in the country, the industry could benefit from it through a low level of capital. This played a role in the emergence of a highly capitalistic Swiss industry which could have been progressively specialized in niche products.

That explains why the Swiss franc has been made 'sacred' through the Gold Standard by these four major Swiss institutions that are the SNB, the Federal Council, the banking and financial industry and the goods industry (Guex, 1999). All four together see in a stable and 
even strong Swiss franc the conditions of Switzerland's wealth. They hence keep instituting and defending orthodox fiscal and overall monetary policy, and then form a coalition whose will is to defend the Gold Stallion. But once again, it is important to highlight that such a coalition is the result of a social struggle because it both implies a strong link between its internal components as well as to neutralize the opponents, with the aim to "overcome the resistance of vested interests and bring about the breakdown of the system and the emergence of a new distribution of social values." (Coser, 1957, p 204)

More precisely, this coalition emerged through a long run process during which the main Swiss economic and politic actors did not always agree with each other. But they nevertheless succeeded in setting up a structural national preference implying a "strong national currency", that is an asset which tends to appreciate against other currencies. The main common reason is that, in spite of the fact that the choice of the Gold Standard implied economic losses in the short run, it allowed developing in the long run a strong national prosperity, which is an explicit goal engraved in the Constitution. Thanks to the national currency, banking, financial and industrial activities have been able to develop and to reinforce the Swiss wealth, which is interesting for the State too. Such a wealth obtained thanks to a powerful currency induces the ability to implement public economic and social programs and the internationalization of the main national sectors, which is a way to exist in the world for a small country like Switzerland.

But more importantly, the Gold Standard implied, during the 1930's, strict orthodox monetary policies as well as fiscal policies, as we have seen. Such a monetary regime was ideal to institute liberal governmental policy, which is a low level of direct State's intervention in the economy. It was also the historic opportunity to destroy any constitution of low social classes which could have fought capital interest (Guex, 1999). To be more precise, the latter have been integrated into the system. Indeed the national coalition born during the 1930's managed to persuade the working class that it was in its interest too to preserve monetary independence thanks to a strong Swiss franc. Even if workers had no direct interest in it as well as other economic actors like farmers, negatively affected by the national currency appreciation and nevertheless very politically influential, this coalition came to demonstrate that the Swiss prosperity was directly linked to the value of the Swiss franc which could entail high real wages for the first and subventions for the second. So they followed the coalition. Furthermore, employers and trade unions signed a historical agreement in 1937 to set up the "social peace" to warrant a "new deal": with the will to prevent social conflicts from jeopardizing the Swiss economy, employers granted frequent bargains to workers (wages, social conditions,...) and in counterpart, labor unions gave up lock out and even automatic appeals to strikes as well as accepted more flexibility on the labor market (Bouquet, 2004).

The previous developments tend to show that the Swiss currency embodies conflicts which have to be analyzed through their structure too (Boudon \& Bourricaud, 1982): either a negative, zero or positive-sum game. In the Swiss case, it seems that it is clearly a positive-sum one because such a conflict, which has been taking place over the time, has a 
cooperative side to it too. It means that the Swiss money is the result of social conflicts that have a regulatory function: to foster national prosperity and to federate Swiss people.

This indicates that money is more than an economic asset: it plays a central role in the settlement of the 'national preference structure' as well as it embodies the collective psychology and then the social link of a country. In other words, we shall adopt a sociological analytical framework to understand, through the relevant Swiss case during the 1930's, to what extent 'money matters' in a country.

\subsection{Why money mattered in Switzerland during the 1930's}

The Swiss monetary experience during the 1930's perfectly explains to what extent money can be perceived as having two dimensions, distinguishable but linked (Baker \& Jimerson, 1992): structural and cultural, each acting at the micro level and at the macro level. The first one focuses on patterns of roles and relationships as well as the whole regulatory context of exchange. We have noticed that the Swiss currency embodies the compromise resulting from the internal social conflicts that lead to a 'national preference structure'. That means that money participates to the macroeconomic and the macro-social regulation process that takes place in a democratic state. From this point of view, the Swiss government can be seen as a federator in last resort, because it seeks to foster the power of the national currency through the preservation of its value for the interests of the main economic sectors.

Stigler (1971) argues that a State is a very useful resource for the latter, and in particular for the goods industry which is highly in favor of it. More than direct subventions, it looks for a political support and economic policies suiting its interests. In the Swiss case during the 1930 's, the defense of the value of the Swiss franc can be assimilated to national protection. And as Stigler indicates too, such government policies aim at improving the interests of society as a whole: as industry is at the core of the national prosperity, the Government has to help it. In the same way, such prosperity allows the Government to gain bargaining power in international negotiations. For instance, at the London Conference on the future of the International Monetary System in 1933, the Swiss delegation was composed of the Federal Council, the SNB but also by the representatives of the industry of goods and of the banking and financial sectors. If this sometimes implies collusion (Rayner, 2011), it has helped the country to have a national project, which is the confidence in the money.

The second one refers to the imaginary link to money which is effective both at the macro and micro levels: values, rules, symbols, myths, beliefs, attitudes. The preservation of the value of the national currency appears to have reinforced the national unity and identity in the Swiss case. The national currency is a result of the central social and political construction that has contributed to national unity and identity. Indeed, as Simmel (1999) emphasized, money does not only concern two persons who are involved in a transaction but put face to face a person and the community who share this money as a whole. If many people accept the same money during the traffic, it means that interdependences take place in such an economy and society. And this eases the social link (Aglietta \& Orléan, 2002). To sum up, "money is also an important medium in the creation of social ties between people. Society is not just a 
collection of individuals, and neither one can be conceived without the other. Through money, relationships between people are established." (Deflem, 2003, p 73).

It is insightful to comprehend why money is at the core of a country's political unification process, being both the realization of the national structures and their vehicle as a source of their legitimacy. As it leads to an objectification of the social interactions and the construction of social links whatever the physical distance, money tends to foster the social links between people who used to be separate earlier. Such a social network works thanks to the "strength of the weak ties" (Granovetter, 1973): those structural properties allow exchanges to take place and to develop, because they are not located in a small community anymore. So the Swiss franc appears to be "the representation of Swiss identity, the symbol of the national autonomy, the neutrality, the Swiss working spirit. In sum; money is an essential identity element, although recent, from which a part of the feeling of membership has been built" (Fior, 2002, p 90).

Those two dimensions of the money have had a strong reality since the 1930's in Switzerland, in particular with regards to the choice of the Gold Standard and its consequences. So the sociological monetary framework is really heuristic to understand how a nation State like Switzerland has managed to build its strength and its unity thanks to the money. During the previous decades, Switzerland has faced monetary tensions that have prevented the country from being economically and politically autonomous. More precisely, even if the country's official political unification was achieved in 1848, Switzerland's situation still depended on abroad. One can deny the fact that the latter changed nothing: as far as the monetary perspective is concerned, the political unification led to lower the circulation of several local currencies on the national territory (Weber, 1988). The first new Swiss franc appeared in 1850 and in 1852, around 65 million of ancient coins were removed.

In spite of this, the country did not possess a unique central bank until 1907. The monetary creation process still strongly depended on 36 private banks before. Moreover, the country faced "monetary chaos" (Campagnolo \& alii, 1999) because several foreign currencies were circulating inside it. Indeed, Switzerland has been committed in the Latin Monetary Union (LMU) with Belgium, France, Greece, Italy, and Luxemburg since 1965. Such a monetary union working on bimetallism (gold and silver) implied for a country to accept the coins of a foreign currency. For Switzerland, this agreement used to reinforce the competition between currencies on its territory and led to the situation that the country was the "monetary appendix" of France (Kugler, 2012). The existence of the Swiss franc was effective to allow the country to be more easily linked to France rather than to link Swiss cantons (Baumann \& Halbeisen, 1999).

That is why the set-up of the Gold Standard took place just after the collapse of the LMU in 1927 and the major economic change that has arisen since World War I: thanks to a solid industrial basis (Boson, 1965; Mazouri, 2005) and above all its neutrality during the conflict, Switzerland was from then seen as a major place to invest in Europe. This led to the development of a strong banking and financial internationalized sector whose importance overcame the French one, showing that "David" was on his way to become "Goliath". Such a 
transformation was incompatible with the existence of the LMU because the latter faced strong economic difficulties due to monetary uncertainties (Dubois, 1950). Conversely, the Golden Standard was an important means to attract foreign investors, and hence to participate to the national prosperity.

In other words, money matters to allow the country as a whole to set up different policies. In spite of the fact that the government preferred liberal economic policies, as we argued, wealth allows the country to exist because it relies on internal solidarity. The Swiss Constitution planned fiscal mechanisms between cantons implying the richest ones helped the poorest ones, contributing to national solidarity. Furthermore, it is important to notice that cantons are stockholders of the Swiss National Bank. This means that they benefit from national monetary policy. Their destiny is closely linked to that of the national monetary policy. One can see on this point that the SNB is one of the only national institutions in Switzerland which contains the word "national" and not "federal".

Moreover, the peg does not only represent an anchor from a technical point of view which means that it has also been an anchor for the building of the social link in Switzerland, as we argued previously: through its acceptation the Swiss people were united around a common project. The latter was to defend the stability and hence the existence of the national currency. This induced the settlement of new economic networks inside Switzerland because, as the structural analysis shows, transitivity exists between several relationships: if the Canton of Geneva exchanges more with the Canton of Lausanne and with the Canton of Bern thanks to the sharing of the same currency, the Cantons of Lausanne and Bern are likely to develop their relationships too. In sum, a unique currency circulating on a territory creates interdependence relationships for the people who are using it (Servet, 2012) as well as entails an endogeneity of monetary integration (Frankel \& Rose, 1997).

In Switzerland, such developments have taken place due to the Swiss franc and particularly through the stability induced by the peg to gold. But the preservation of the value of the money prevents Swiss people from losing confidence in their national currency too. Conversely, due to the fact that a strong Swiss franc eases national prosperity and high purchasing power, it prevents the country from facing violent conflicts. In other words, because money could be possessed for itself as it embodies power, the national authorities like the SNB in the Swiss case have to ensure that it fits the collective interests.

That is why the Swiss case tends to demonstrate that, from a political point of view, the "denationalization of money" (Hayek, 1978) is not necessarily practicable and desirable. Beyond the fact that such an approach underestimates the economic costs associated like costs of transaction or property rights (Le Maux, 2007), it could create a competition between the different currencies that could jeopardize the monetary networks and then the social link within the country. It is strongly the case for this country which is simultaneously a small open economy and a heavily diversified society, with multi internal identities. The national currency plays the role of a collective good that offers a protection for the whole nation State pulled in this context between centrifugal forces and centripetal forces. 
And as its existence is frequently threatened for those reasons, such a currency has to be credible and reliable. That is why conversely to what Hayek argued, the Swiss case shows that a Government does not always abuse of its monetary prerogative thanks to the monopole of the money. In other words, the latter does not always lead to a "largely inflation engineered by government" (Hayek, 1978, p 33). At the opposite, it could imply a "skinny" government to prevent the money from depreciating thanks to the orthodox economic and monetary policies setup. Because people, even more if they belong to different cultures, have to trust the money they use. If not, they will reject it. Thus such a monetary regime, if it reaches the forecasted effects, participates in revealing two important dimensions it embodies: acceptability and stability. It indirectly is a protection against State interventionism, so it is a kind of democratic control of it.

If competition between currencies could without any doubts entail the same economic positive effect as fixed exchange rates (discipline), we nevertheless argue that the consequences would not be the same: on the one hand (competition), it could potentially split up a territory; on the other hand, it could conversely reinforce its unity and federate the population thanks to a common project that money embodies. Maybe that is why the Swiss central bank has the 'national' brand and not only the 'federal' one. The choice of the words has a true sense here. And as the Political leader Musy sums up in the 1930's: "One has said with reason that our Swiss franc is the main column on which our national political building is based. We have to preserve it [...]. With such an economic structure as ours, one can consider the money as the single big financial enterprise from which all the Swiss people, whatever the economic groups they belong to, are interested in" (Musy, 1933, p 571).

\section{Conclusion}

As both a small open economy and a multicultural country, Switzerland is at the core of centrifugal and centripetal forces that could jeopardize its unity, and even its existence. Such a situation necessitates strong anchor to allow the Swiss people to federate and the country to internationally exist. The national currency is actually one of the primary means allowing the Swiss citizens to access to wealth, to live together and to have a specific identity. In other words, the Swiss franc is one of the determinants of the both internal as well as external confidence. That is why strong ties exist between the economic, monetary, financial and political dimensions in the Swiss case: the Swiss wealth gives it political bargaining power, allowing them to exist internationally in spite of its small size (Perrenoud, 2005).

In order to understand this, one has focused on the 1930's, a period during which the Swiss authorities and the main economic sectors have decided to implement the Gold Standard. We have attempted to demonstrate that such a monetary regime was more than just a cyclical and technical choice. It has also participated in reinforcing the power of the national currency, that is to say first by attracting international capital inflows. Secondly, it has implied the emergence and the preservation over the time of a Swiss mentality in favor of the stability of the money. The latter is then at the core of the Federal Council and the SNB's preoccupations when they act for the economy and the society: even if Swiss economic and monetary 
policies are in general opposed to interventionism and étatisme, they demonstrate through their vision of the Swiss franc their will to implement not a 'Big State' in size but in aim.

Such a mentality plays the role of a social and political anchor too. This explains why 'money matters' in Switzerland and why its monetary situation has to adopt an analytical framework mixing an economic and sociological perspective. The idea of the 'violence' of money (Aglietta \& Orléan, 2002) has to be understood here from this point of view because it could be perceived as a result of social conflicts allowing national regulation. In other words, money reflects the 'national preference structure' the country wants to implement. Hence the previous developments are very insightful to comprehend why the country has been so reluctant to contemplate any European Union's full accession for more than fifty years and symmetrically perhaps, why the European monetary project is still even more far from achievement.

\section{Acknowledgements}

I am very grateful to my sister Fabienne and to Siddharta Sanghi for their precious help and advice for the English language. Thank you so much.

\section{References}

Adank, F., Baumann, J, Cortat A., Lopez, R., Perrenoud, M., \& Peters, S. (2002). La place financière et les banques suisses à l'époque du national-socialisme. Les relations des grandes banques avec l'Allemagne (1931-1946), Zürich, Publication de la CIE-UEK.

Aglietta, M., \& Orléan, A. (2002). La monnaie entre violence et confiance. Paris, Odile Jacob.

Baker, W.E., \& Jimerson, J.B. (1992). The Sociology of Money. The American Behavioral, 35(6), 678-693. http://dx.doi.org/10.1177\%2F0002764292035006005

Baumann, J., \& Halbeisein, P. (1999). "Die Internationalisierung des Finanzplatzes Schweizund ihre Folgen für die Währungspolitik: Konsens und Konflikte zwischen der Nationalbank und den Geschäftsbanken 1919-1939", Colloque "Switzerland as a financial centre in international perspective (1913-1964). Lausanne, 1 et 2 octobre.

Bordo, M., Helbling T., \& James H. (2006). Swiss Exchange Rate Policy in the 1930's. Wasthe Delay in Devaluation too High a Price to Pay for Conservatism?. NBER Working Papers, n12491, August.

Boson, M. (1965). Coop en Suisse. Bâle, Imprimerie de l’USC Bâle.

Boudon, R., \& Bourricaud, F. (1982). Dictionnaire critique de sociologie. Paris, PUF.

Bouquet, J.J. (2004). Histoire de la Suisse. Paris, PUF. 


\section{Macrothink}

Calvo, G., \& Reinhart, C. (2002). Fear of Floating. The Quarterly Journal of Economics, MIT Press, n117, May. http://dx.doi.org/10.1162\%2F003355302753650274

Campagnolo, M., De Rivaz, M., \& Lesca, B. (1999). Une monnaie pour la Suisse. Genève, Editions Suzan Hurter.

Clarida, R., \& GALÍ, J. (1994). Sources of Real Exchange Rate Fluctuations: How Important are Nominal Shocks?. NBER working paper 4658.

Conseil Fédéral Suisse. (1933). Message du Conseil fédéral à l'Assemblée fédérale concernant les mesures extraordinaires et temporaires destinées au rétablissement de l'équilibre budgétaire du 2 septembre 1933 , Feuille fédérale, II, pp 201-298.

Coser, L.A. (1957). Social Conflict and the Theory of Social Change. The British Journal of Sociology, 8(3), 197-207. http://dx.doi.org/10.2307\%2F586859

Coudert, V., \& Raymond, H. (2011). Gold and financial assets: are there any safe havens in bear markets. Economics Bulletin, 31(2), 1613-1622.

Cruchon, A. (1932). Le Franc suisse pendant et après la guerr. Payot, Lausanne.

Dalton, G. (1967). "Primitive Money", in Dalton G. (Ed.), Tribal and Peasant Economies, Austin, University of Texas Press.

Deflem, M. (2003). "The Sociology of the Sociology of the Money", Simmel and the Contemporary Battle of the Classics. Journal of Classical Sociology, 3(67), 66-96.

Dubois, L.A. (1950). La fin de l'Union monétaire latine, Thèse de doctorat ès sciences commerciales et économiques, Université de Neuchâtel, Neuchâtel.

Eichengreen, B., \& Temin, P. (2000). The Gold Standard and the Great Depression. Contemporary European History, 9(2), 193-207.

Fior, M. (2002). Les banques suisses, le franc et l'Allemagne. Genève, Librairie Droz.

Frankel, J., \& Rose, A. (1997). Is EMU more justifiable ex post than ex ante? European $\begin{array}{lll}\text { Economic } & \text { Review, } & \text { 753-760. }\end{array}$ http://dx.doi.org/10.1016\%2FS0014-2921\%2897\%2900034-2

Granovetter, M. (1973). The Strength of Weak Ties. American Journal of Sociology, 18(6), 1360-1380. http://dx.doi.org/10.1086\%2F225469

Guex, S. (1999). Les origines du secret bancaire suisse et son rôle dans la politique de la Confédération au sortir de la Seconde Guerre mondiale. Genèses, 34, 4-27.

Guillaumin, C., \& Vallet, G. (2012). La Suisse et la zone euro: votre monnaie, notre problème? La possibilité d'un ancrage de jure. Revue d'Economie Politique, 122(5), 629-655.

Hayek, F.A. (1976). Denationalization of Money. The Argument Refined. London, The Institute of Economic Affairs. 
Kugler, P. (2012). Une monnaie si forte pour un si petit pays: chance ou malchance? La vie économique. Revue de politique économique, 1/2, 27-30.

Kugler, P., \& Weder, B. (2009). The Demise of the Swiss Interest Rate Puzzle. Paper prepared for the SNB-IMF Conference on exchange rates, November $24^{\text {th }}$ and $25^{\text {th }} 2008$, Zürich.

Lampart, D. (2011). Effets d'une appréciation du franc sur l'économie suisse, Union Syndicale Suisse, www.uss.ch, Dossier n71, janvier.

Le Maux, L. (2007). Une théorie de la marque monétaire. L'impossibilité de la dénationalisation de la monnaie. Revue Economique, 58(5), 985-1009.

Mazbouri, M. (2005). L'émergence de la place financière suisse, 1890-1913, Lausanne, Editions Antipodes.

Müller, P. (2003). La bataille pour le franc: la Suisse entre deflation et devaluation (1931-1936), in Müller P, Paccaud, I. \& Schaufelbuehl, J.M., 2003, Franc suisse, finance et commerce, Editions Antipodes, Lausanne, pp 7-145.

Musy, J.M. (1933). Déclaration au Conseil Fédéral, Conseil Fédéral, 26 septembre.

Perrenoud, M. (2005). La place financière suisse en tant qu'instrument de la politique étrangère helvétique. Relations Internationales, 121, 25-42.

Ponsot, J.F., \& Vallet, G. (2012). L'énigme du franc Suisse ou comment concilier intégration à l'euro et souveraineté monétaire. Cahiers de recherche du CREG, 3(26).

Ranaldo, A., \& Söderlind, P. (2010). Safe Haven Currencies. Review of Finance, 14(3), 385-407. http://dx.doi.org/10.1093\%2Frof\%2Frfq007

Rayner, H. (2011). Suisse. Vers une crise du «gouvernement de tous les partis»? Grande Europe, n33, juin.

Schriber, M. (2007). Le secteur bancaire suisse: une histoire à succès, mais aussi à risque. Revue de politique économique, 4, 44 - 48.

Servet, J.M. (2012). Les monnaies du lien. Lyon, PUL.

Simmel, G. (1999). Philosophie de l'argent. Paris, PUF [First published in 1900].

Stigler, G. (1971). The Theory of Economic Regulation. The Bell Journal of Economics and Management Science, 2(1), 3-21. http://dx.doi.org/10.2307\%2F3003160

Touraine, A. (1994). Qu'est-ce que la démocratie? Paris, LGF.

UBS (2000). The Future of the Swiss Franc. Independence or clinging to the euro boat ?. UBS Group Economic Research Studies, October.

Vallet, G. (2012). Should I Stay or Should I Go? Switzerland and the European Economic and Monetary Integration Process. Journal of Economic Integration, 27(3), 366-385. http://dx.doi.org/10.11130\%2Fjei.2012.27.3.366 


\section{Macrothink}

Weber, E.J. (1988). Currency Competition in Switzerland. Kyklos, 41, 459-478.

Weber, M. (1922). Economy and Society. Berkeley, University of California Press.

Zurlinden, M. (2003). Régime de l'étalon-or, déflation et dépression: l'économie suisse dans la crise économique mondiale. Bulletin trimestriel de la BNS, 2, 86-116.

\section{Copyright Disclaimer}

Copyright reserved by the author(s).

This article is an open-access article distributed under the terms and conditions of the Creative Commons Attribution license (http://creativecommons.org/licenses/by/3.0/). 